DOI: $10.21802 /$ artm.2020.3.15.98.

УДК 616.5-003.829-089-053

\title{
ДЕЯКІ ПИТАННЯ ХІРУРГІЧНОЇ ТАКТИКИ В ЛІКУВАННІ ПІГМЕНТНИХ НЕВУСІВ У ДІТЕЙ
}

\author{
В.С. Конопліцький, О.В. Пасічник, О.О. Калінчук, Д.В. Конопліцький, С.С. Блажко
}

Вінницький національний медичний університет, кафедра дитячої хірургії, м. Вінниця, Украӥна,

ORCID ID: 0000-0001-9525-1547, ORCID ID: 0000-0001-8302-3520,

ORCID ID: 0000-0002-1918-0035, ORCID ID: 0000-0002-1320-0541,

ORCID ID: 0000-0003-4891-5886,

e-mail:vkonoplytsky@gmail.com

Резюме. Стаття містить актуальну інформацію щодо діагностики та лікування дітей з меланоцитарними невусами, форми яких зустрічаються найчастіше, з вказівкою на їх динамічну еволюцію 3 часом. Обговорюються фактори ризику та питання ранньої діагностики меланоми в загальній практиці. Також обговоренню підлягає сучасне розуміння ризиків, пов'язаних з вродженими меланоцитарними невусами різних розмірів, $\mathrm{i}$ стратегії лікування дітей з вродженими і набутими меланоцитарними невусами.

Метою дослідження було підвищення якості лікування дітей шляхом уточнення показів і методів хірургічного лікування пігментних невусів шкіри.

Пігментні невуси відносяться до доброякісних утворень, виникнення яких на сучасному етапі пов'язують 3 міграцією в ембріональному періоді меланобластів із нейроектодермальної трубки в базальний шар епідермісу. У дітей пігментні невуси зустрічаються досить часто в будь-якому віці. Так у новонароджених пігментні невуси зустрічаються в 1-6\% загальної популяції. Покази до профілактичного видалення невусів витікають із проведеного аналізу клінічного матеріалу: наявність симптомів активації, зокрема ріст невуса; наявності в анамнезі факторів, що сприяють активації пігментних невусів - підвищена сонячна інсоляція, травматизація, зміна гормонального фону; наявність ознак клітинної проліферації; наявність вогнища термонагріву в проекції пігментного невуса. Обов'язковою умовою виконання операції повинно бути проведення морфологічного дослідження. Об'єм тканин, що видаляються, залежить від форми росту, розмірів невуса.

Ключові слова: невус, діагностика меланоми.

Вступ. Термін "невус", (лат. - родима пляма, рубець) вперше застосував R. Virchow (1863 р.) для позначення родимих пігментних плям шкіри. Більш широке тлумачення надав J. Jadasson (1914), включивши в цю групу вади розвитку та деякі доброякісні пухлини шкіри. Справжнє значення терміна "невус" передбачає наявність у новоутвореннях меланоцитів або невусних клітин. Всі варіанти справжніх невусів $€$ похідними меланоцитів, клітин, що продукують меланін, чим і пояснюється колір новоутворень, які за класифікацією ВООЗ належать до гамартом, що підтверджує їх дизембріональне походження [1].

У дітей ПН зустрічаються досить часто в будь-якому віці. Так у новонароджених ПН зустрічаються в 1-6\% загальної популяції [2].

Пігментні невуси (ПН) відносяться до доброякісних утворень, виникнення яких на сучасному етапі пов'язують 3 міграцією в ембріональному періоді меланобластів із нейроектодермальної трубки в базальний шар епідермісу. Згідно 3 дослідженнями останніх років, у дітей невуси розділяють на вроджені меланоцитані, які являють собою гамартому внаслідок клональної проліферації доброякісних меланоцитів у період ембіогенезу, що можуть існувати вже при народжені або з'являтись протягом перших років життя (феномен відстроченої клінічної маніфестації), та набуті меланоцитарні, які є доброякісними пухлинами, що виникають із меланоцитів, що мігрували у шкіру в ембріональному періоді після 6 місячного віку, досягають максимальних розмірів в юнацькому віці, а в подальшому схильні до регресії та повного зникнення [3, 4]. До факторів, які сприяють виникненню набутих невусів, відносять: сімейну спадковість; надлишок УФО в дитинстві, особливо 3 утворенням бульозного епідермолізу; деякі ендокринні стани; фенотипові особливості (світла шкіра із значенням I-II фото типу за Фіцпатриком, особливо у поєднанні з рудим волоссям) [5].

Всі невуси розподіляють на меланомонебезпечні (пігментний невус пограничний, блакитний невус, невус Отта, гігантський пігментний невус, меланоз Дюбрея) та умовно безпечні (внутрішньодермальний пігментний невус, фіброепітеліальний невус, папіломатозний та веррукозний невус, "монгольська пляма" (Halo-невус Сеттона) [6].

Загалом ПН поєднує ряд гамаром шкіри із загальними клінічними та гістологічними ознаками; це вади розвитку, які сформовані зрілими або майже зрілими компонентами епідермісу, сальних залоз, волосяних фолікулів, апокринних та еккринних потових залоз та їх комбінаціями. ПН у 80\% випадків відмічаються на першому році життя та носять спорадичний характер [7]. 
Обгрунтування дослідження. При наявності великої кількості ПН у однієї особи, вони зазвичай мають спільні клінічні характеристики (signature nevus) у вигляді рожевих, коричневих, чорних утворень із ексцентричною пігментацією та іншими ознаками, які повторюються у конкретного пацієнта. У формуванні типових характеристик ПН можуть брати участь також множинні галоневуси. Визначення типових ознак ПН у пацієнта дозволяє виділити із загальної кількості окремі підозрілі характеристики на недоброякісний характер утворення (правило "бридкого каченяти") [8, 9].

У процесі життя деякі ПН, особливо диспластичні, можуть проходити трансформацію в злоякісну пухлину-меланому, яка становить біля 0,3-0,9\% всіх злоякісних пухлин у дітей віком до 14 років [10, 11, $12]$.

Меланома рідко зустрічається у дітей, особливо у препубертатному періоді. За даними реєстру "Спостереження. Епідеміологія та кінцеві результати онкологічних захворювань" з 2000 по 2010 рр. меланома діагностована у 1185 дітей (вік 0-18 років), із них у $11 \%$ у пацієнтів до 9 років, а в $89 \%$ - у віці 310 до 18 років. Було зазначено, що лікарями неправильно діагностується меланома в педіатричній практиці, тому що вона не обов'язково містить типові дерматоскопічні ознаки системи $\mathrm{ABCD}$, тому потрібне більш глибоке розуміння перебігу патології у дітей $[13,14]$.

Крім того, у практичній діяльності зустрічаються випадки, коли в ділянці видалення ПН, навіть через декілька років, у післяопераційному періоді 3'являються вогнища пігментації [15]. За класифікацією ВОО3, такі невуси виділені в групу "персистуючого росту невуса" (persistent melanocytic naevus), так як рецидив у меншій мірі відповідає гістогенезу цього процесу. У залежності від локалізації та характеру пігмент продукуючих клітин можливе визначення гістологічного діагнозу продовженого росту невуса 3 вказівкою на варіант його будови. Найбільш часто визначаються прості ПН на різних стадіях інволюції: змішані, внутрішньодермальні, фібротизовані. Основною причиною персистенції невуса $є$ неповне видалення клітин, що продукують меланін, які залягають глибоко у дермі при внутрішньодермальному варіанті простого невуса. Основним та найбільш адекватним методом попередження персистенції невуса деякі автори вважають електрокоагуляцію ложа після видалення новоутворення в межах дерми, що визначається глибиною розташування невусних клітин [16, 17]. Але методологія такого втручання остаточно не розроблена, має багато невирішених питань, а саме: які ПН підлягають комбінованому методу ексцизії, який вид енергії та які їі характеристики повинні бути обрані тощо [9].

Таким чином актуальність даної роботи полягає у вивченні можливостей удосконалення хірургічного лікування ПН у дітей.

Мета дослідження: підвищити якість лікування дітей шляхом уточнення показів та методів хірургічного лікування пігментних невусів шкіри.
Матеріали і методи. У відділенні онкогематології Вінницької обласної дитячої клінічної лікарні з 2010 по 2019 рр. прооперовано 453 хлопчиків та дівчат віком від 1 до 18 років з ПН різної локалізації. Всі госпіталізовані діти знаходились на обліку в дитячого онколога та не мали протипоказів до оперативного лікування. Хірургічне лікування передбачало висічення ПН, променеву коагуляцію ложа невуса, а при гігантських ПН етапне висічення невуса із заміщенням дефекту місцевими тканинами у вигляді ротаційних клаптів, товстим розщепленим або повношаровим шкірним аутотрансплантатом. При "дефіциті" місцевих тканин у 12 пацієнтів застосовували метод експандерної дерматензії.

Променеву коагуляцію виконували за допомогою діодного лазера "LIKA- Surgeon+" (Україна) 3 довжиною хвилі 940 нм та потужністю 10 Вт.

Вилучені інтраопераційно зразки тканин фіксували в $10 \%$ водному розчині нейтрального формаліну протягом 48 годин, зневоднювали у системі багатоатомних спиртів висхідної концентрації з подальшим виготовленням парафінових блоків. Виготовлені зрізи препаратів завтовшки 5-7 мкм забарвлювали гематоксиліном та еозином. Вивчення забарвлених мікропрепаратів, їх структурне дослідження із обов'язковою фотофіксацією виконували на морфометричному комплексі Olympus Imaging CORP Model No E - 410 DC 7:4 VD 56547931 при збільшеннях у 100 та 200 разів.

Результати дослідження. Аналіз щорічної частоти локалізації ПН в загальній групі дослідження (n=453) з'ясував, що утворення в ділянці губ спостерігалось у 0,88\% випадків, повік - 0,88\%, вушних раковин та зовнішнього вуха - $0,66 \%$, обличчя $10,38 \%$, зони волосистої ділянки голови, шиї $11,36 \%$, тулуба - 49,89\%, верхньої кінцівки разом із надпліччям - 10,74\%, нижньої кінцівки разом 3 ділянкою сідниць та кульшового суглобу - 13,79\%, неуточнена локалізація визначалась в 1,42\% спостережень (табл. 1). Серед загальної кількості пацієнтів у 12 дітей були діагностовані гігантські пігментні невуси, які вимагали етапних хірургічних втручань (загалом 32 операціï), у 9 (1,98\%) випадках, внаслідок рецидивного перебігу патології, проведені повторні оперативні втручання. Таким чином кількість оперативних втручань у загальній групі пацієнтів складала 503 епізоди.

Зважаючи на зведені дані Таблиці 1, щорічна середня прогнозована кількість оперативно пролікованих пацієнтів відповідає величині 45,3 випадку/рік. Беручи до уваги той факт, що кількість дітей віком до 18 років у Вінницькій області станом на 1.01.20202 p. становить 285689 осіб, можливо припустити, що орієнтовна поширеність оперативно пролікованої патології знаходиться в межах $\approx 0,0159 \%$.

Аналіз динаміки щорічної кількості дітей, оперованих з приводу ПН різної локалізації виявив їі експоненціальний приріст (рис. 1). 
Таблиця 1

Щорічний розподіл паціснтів за локалізацією невусів

\begin{tabular}{|c|c|c|c|c|c|c|c|c|c|c|}
\hline \multirow[b]{2}{*}{ Локалізація за МКХ10 } & \multicolumn{10}{|c|}{ Роки } \\
\hline & 2010 & 2011 & 2012 & 2013 & 2014 & 2015 & 2016 & 2017 & 2018 & 2019 \\
\hline D22.0/ губа & - & - & 2 & - & 1 & - & - & - & 1 & - \\
\hline D22.1/ повіка & - & - & - & - & 1 & - & - & 1 & - & 2 \\
\hline D22.2/ вухо & - & 1 & - & - & - & 1 & - & 1 & - & - \\
\hline D22.3/ лице & 5 & 5 & 4 & 4 & 5 & 2 & 7 & 5 & 4 & 6 \\
\hline D22.4/ голова-шия & 1 & 3 & 7 & 4 & 4 & 4 & 7 & 4 & 10 & 7 \\
\hline D22.5/ тулуб & 11 & 32 & 30 & 14 & 23 & 23 & 20 & 11 & 31 & 31 \\
\hline D22.6/ верхня кінцівка & 2 & 7 & 3 & 3 & 4 & 12 & 8 & 2 & 6 & 1 \\
\hline D22.7/ нижня кінцівка & 1 & 8 & 6 & 8 & 5 & 5 & 10 & 7 & 7 & 8 \\
\hline D22.9/ неуточнений & - & - & - & - & - & - & 1 & 1 & 2 & 2 \\
\hline Всього (453) & 20 & 56 & 52 & 33 & 42 & 47 & 53 & 32 & 61 & 57 \\
\hline
\end{tabular}

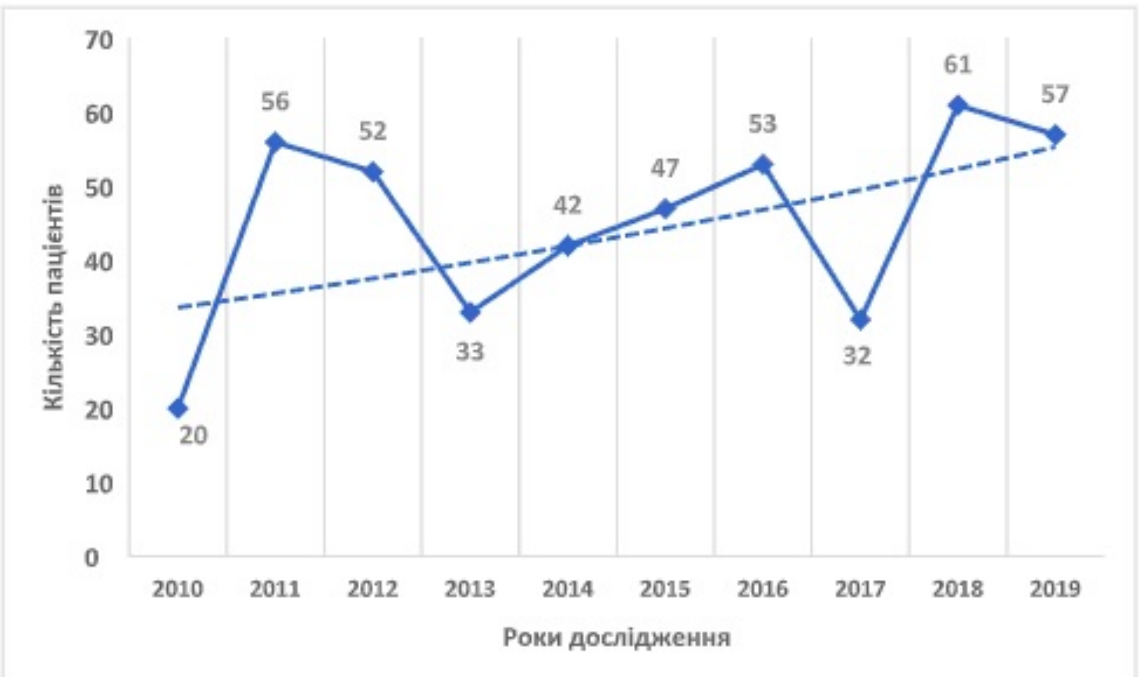

Рис. 1. Експоненціальний щорічний приріст кількості оперованих дітей з ПН 2010 - 2019 рр.

За даними гістологічних досліджень видалених препаратів, серед 453 пацієнтів у 23 дітей (5,08\%) було виявлено меланому.

3 появою на початку 2017 р. лазерного коагулятора, у 140 пацієнтів, у період з 2017 по 2019 рр., післяопераційне ложе ПН підлягало обов'язковому хвильовому опроміненню незалежно від розмірів утворення, і в тому числі перед накладенням швів на шкіру. Даний апарат з довжиною хвилі в інфрачервоному діапазоні (940 нм) був обраний внаслідок того, що має добре іiї поглинання як у воді, так і в оксигемоглобіні, а тому оптимально поєднує в собі ріжучі та коагулюючі властивості (рис. 2).

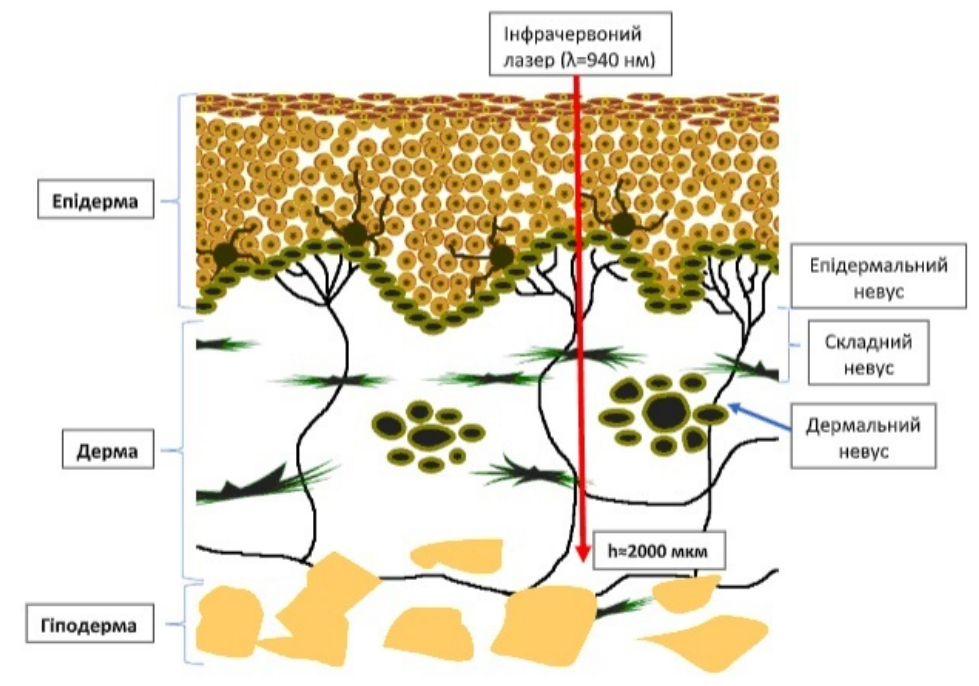

Рис. 2. Просторова схема морфологічного співвідношення локалізації невусів відносно шарів шкіри 
Обговорення результатів. Серед дитячої популяції ПН зустрічаються дуже часто і в будь якому віці, однак далеко не всі вони потребують оперативного видалення. Враховуючі дані і рекомендації інших дослідників та базуючись на власному багаторічному досвіді лікування пігментних невусів у дітей, розроблені певні покази по відбору пацієнтів до оперативного лікування:

- бурхливий ріст та видимі візуальні зміни параметрів невуса;

- утворення вузликів одночасно із пігментацією невуса (рис.3);

- $\quad$ зміна кольору утворення (потемніння або просвітлення);

- поява запального інфільтрату у вигляді

кільцеподібної гіперемії навколо утворення;

- $\quad$ випадіння з поверхні пігментного невуса волосків ("облисіння");

- поява на поверхні утворення тріщин та виразок;

- $\quad$ кровотеча або інші виділення із невуса;

- зміна консистенції утворення (ущільнення/розм'якшення);

- поява болю, свербежу;

- гігантські пігментні невуси, а також діаметр утворення $>0,5 \mathrm{~cm}$;
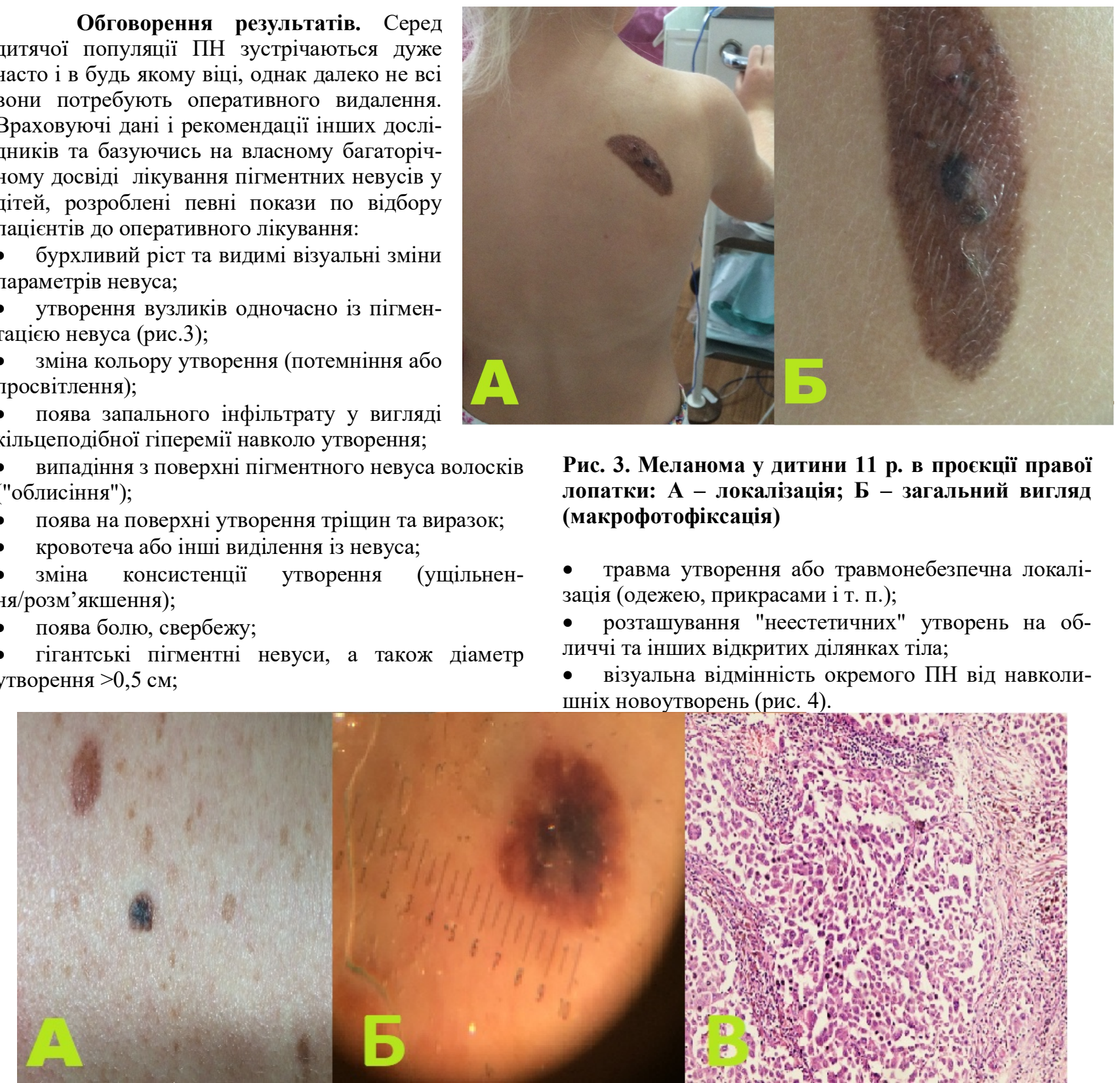

Рис. 3. Меланома у дитини 11 р. в проскції правої лопатки: А - локалізація; Б - загальний вигляд (макрофотофіксація)

- травма утворення або травмонебезпечна локалізація (одежею, прикрасами і т. п.);

- розташування "неестетичних" утворень на обличчі та інших відкритих ділянках тіла;

- візуальна відмінність окремого ПН від навколишніх новоутворень (рис. 4).

Рис. 4. Візуальна відмінність ПН від навколишніх тканин: А - правило "бридкого каченяти";

Б - дерматоскопічні ознаки: біло-блакитна структура, асиметрія будови, атипова пігментна мережа); В - морфологічні ознаки меланоми (великі пухлинні клітини, у цитоплазмі яких та позаклітинно визначається відкладання меланіну, поодинокі гігантські багатоядерні пухлинні клітини, вогнища лімфоїдної інфільтрації). Забарвлення гематоксилін та еозин. Зб.: × 200.

Серед 303 пацієнтів, які були прооперовані в період з 2010 по 2016 рр. включно (тобто до застосування лазерної коагуляції), у 9 (2,97\%) випадках спостерігався "рецидивний" перебіг захворювання в терміни від 6 місяців до 2-х років після первинної ексцизії утворення, що потребувало повторного висічення змінених м'яких тканин у ділянці первинного оперативного втручання.

Гістологічний аналіз видалених при повторному втручанні зразків тканин виявив певні морфологічні зміни, які пояснювали клінічну картину персис-

туючого росу ПН, а саме: на тлі рубцевих змін у зоні пігментації визначались меланоцити або невусні клітини, що залишилися після видалення, у цитоплазмі яких містились темно-коричневі гранули пігменту меланіну (рис. 5).

Серед 12 пацієнтів $з$ гігантськими вродженими меланоцитарними невусами у двох випадках у післяопераційному періоді спостерігався продовжений ріст у вигляді появи пігментованих ділянок у зоні рубця розмірами від 0,3 до $0,6 \mathrm{~cm}$. 


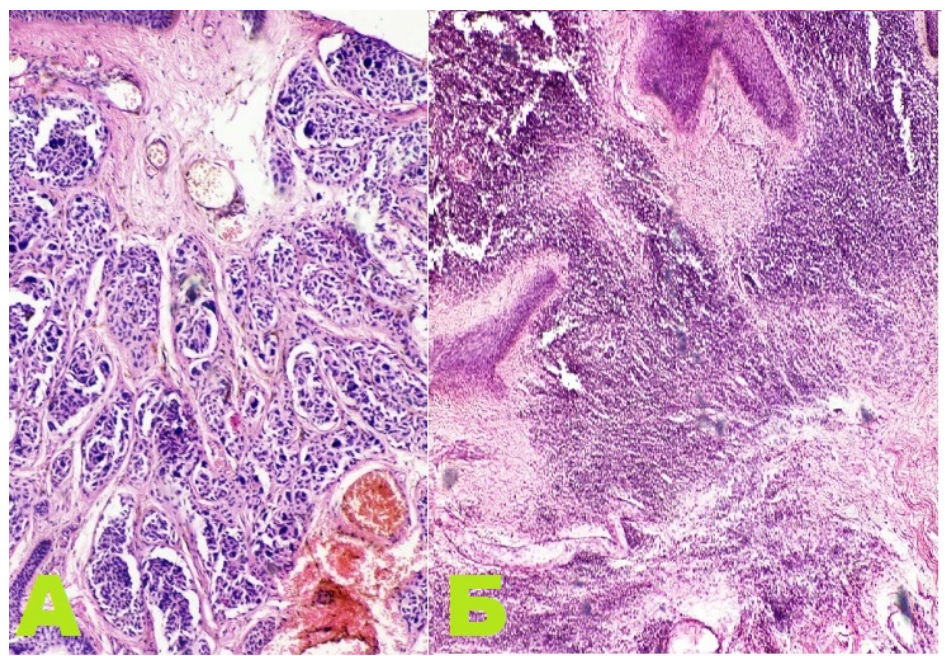

Рис. 5. Персистуючий ріст пігментного не-

вуса. Забарвлення гематоксилін та еозин.

3б.: $\times$ 100. А - гнізда невусних клітин глибоко в

дермі, навколо судин та волосяних фолікулів;

Б - глибокий ріст невуса

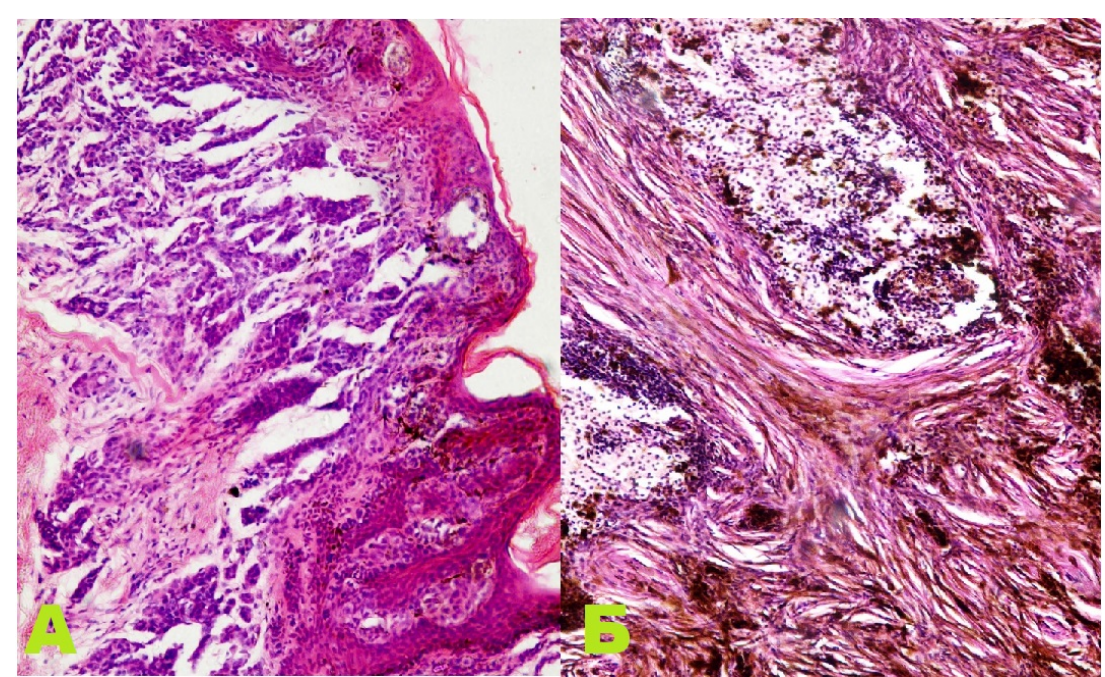

При морфологічному дослідженні гігантських невусів у жодному випадку меланоми виявлено не було, однак ділянки диспластичного невуса розцінювались як потенційно загрозливі в плані малігнізації.

Оперативне видалення гігантських вроджених невусів у зв'язку з ознаками передмеланомних процесів та наявності вогнищ запалення, у певному ступеню носять ексклюзивний характер, що пов'язано із значними технічними труднощами, необхідністю поетапної резекції меланоцитарного утворення.

Iз 12 пацієнтів 3 гігантськими пігментними невусами в 5 випадках виконували пластику шкіри, а у 7 дітей застосовували метод балонної дермотензії (рис. 7).

Після повторних висічень проблемних ділянок, краї рани у всіх пацієнтів даної групи опромінювали лазерним коагулятором із наступною обробкою ранової поверхні спиртовим розчином антисептика перед ушиванням їі країв.
При гістологічному дослідженні цих ділянок серед грубоволокнистої рубцевої тканини субепідермально визначались скупчення пігментних невусних клітин, що характерно для простого внутрішньодермального невуса, або скупчення веретеноподібних клітин блакитного невуса. У випадку із морфологічними ознаками блакитного невуса визначено, що у верхній частині сітчастого шару дерми та значно глибше визначаються подовжені відростчасті меланоцити, заповнені меланіном. Визначаються вогнища фібротизації невуса з глибоким зануренням пігменту в дерму (рис. 6).
Рис. 6. Персистуючий ріст вродженого гігантського меланоцитарного невуса. Забарвлення гематоксилін та еозин. 3б.: $\times 200$. А - сосочковий шар дерми у якому на великій площі визначаються чисельні густі скупчення меланоцитів в оточенні сполучнотканинних елементів; Б - морфологічна будова блакитного невуса 3 балонізацісю невусних клітин, вогнищами фібротизації 


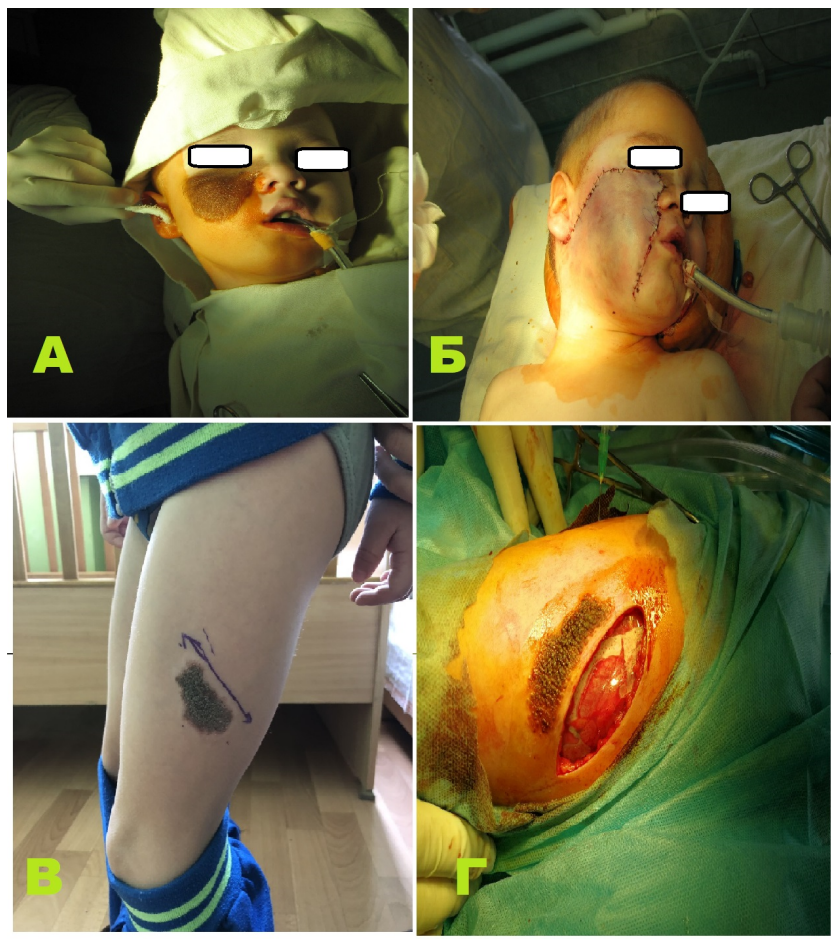

Рис. 7. Методики видалення вроджених гігантських невусів: A - невус обличчя (загальний вигляд), Б - пластика шкіри; В - невус стегна (загальний вигляд), Г - постановка експандеру

Через це персистуючий ріст виникає не внаслідок глибини проростання, а через радіальне епідермальне розповсюдження вогнищ диспластичного високопігментного новоутворення. За таких умов, зазвичай межі його чітко визначаються, що дозволяє виконувати ексцизію в межах здорових тканин на всю глибину дерми, як при внутрішньодермальному розташуванні ПН.

Висновки. Зважаючи на велику кількість ПН різної локалізації в дитячому віці та ретельний підхід до визначення показів до оперативного лікування, в останнє десятиліття спостерігається екстенціальний щорічний приріст кількості оперованих дітей. Покази до оперативного видалення ПН у дитячому віці повинні базуватись на чітких клінічних динамічних ознаках, у першу чергу з урахуванням локалізації в функціонально активних ділянках. 3 метою профілактики персистуючого росту ПН будь-яких розмірів доцільна їх ексцизія в межах здорової шкіри по окружності до фасціального шару 3 одночасним опроміненням лазерним коагулятором із довжиною хвилі 940 нм.

\section{References:}

1. Degtyarev OV, Dumchenko VV, Shashkova AA, Alieva ER, Hayrulin YuH. Vrozhdennyie nevusyi u detey. Rossiyskiy zhurnal kozhnyih i venericheskih bolezney. 2013; 4:8-10.

2. Ali MG, Gamal AD. Ultra-pulsed carbon dioxide laser for the treatment of melanocytic nevi. J Cosmetology. 2019; 3(1):1-6.
3. Sogutcu N. Unusual histopathological findings of intradermal nevus: retrospective analysis of 2640 cases. J Dicle Med. 2019; 46(3):575-581.

4. Ghosh A, Ghartimagar D, Thapa S, Sathian B, Shrestha B, Talwar OP. Bening melanocytic lesions with emphasis on melanocytic - a histomorphological analysis. Journal of Pathology of Nepal. 2018; 8:1384-1388.

5. Schaffer JV. Pigmented lesions in children: when to worry. Curr Opin Pediatr. 2007; 19(4):430.

6. Byistrov AV, Gassan TA, Soboleva EYu, i dr. Hirurgicheskoe lechenie vrozhdennyih pigmentryih nevusov u detey. Detskaya bolnitsa. 2016; 4:26-30.

7. Ufimtseva MA, Spirin AV, Gagiev VV, Chernyadev SA, BochkarYov YuM, Shubina AS, i dr. Epidermalnyiy nevus: opisanie klinicheskogo nablyudeniya. Sovremennyie problemyi nauki i obrazovaniya. 2019; 3:202-209. Available from:-http://www.scienceeducation.ru/ru/article/view?id $=28980$

8. Voronina VR. Melanotsitarnyie nevusyi u detey: izmenyayuschiesya obrazovaniya u rastuschih patsientov. Praktika pedIatra. 2019; 1:36-41.

9. Sardana K, Chakravarty P, Goel Kh. Optimal management of comm0n acquired melanocytic nevi (moles): current perspectives. Clinical, Cosmetic and Investigational Dermatology. 2014; 7:89-103.

10. Romanova OA, Artemeva NG, Solohina MG. Klinicheskiy sluchay progressiruyuschego displasticheskogo nevusa $\mathrm{s}$ perehodom $\mathrm{v}$ melanomu. Klinicheskaya dermatologiya i venerologiya. 2018; 17(2):34-37.

11. Romanova OA, Artemeva NG, Yagubova EA, Rudakova IM, Maryicheva VN, Veschevaylov AA. Taktika vedeniya patsienta $\mathrm{s}$ displasticheskim nevusom. Klinicheskaya dermatologiya i venerologiya. 2015; 2(14):92-97.

12. Ismail-Zade RS. Melanoma kozhi u detey. Onkologiya. Zhurnal im. P.A. Gertsena. 2013; 3:40-44.

13. Bakulev AL, Konopatskova OM, Stanchina YuV. Dermatoscopy in the diagnosis of pigmented nevi. Vestnik Dermatologii i Venerologii. 2019; 95(4):4856. Available from: https://doi.org/10.25208/00424609-2019-95-4-48-56

14. Bartenstein DW, Kelleher CM, Friedmann AM, et al. Contrasting features of childhood and adolescent melanomas. Pediatric Dermatology. 2018; 35:354-360. Available from: https://oi.org/10.1111/pde.13454

15. Green MC, Mitchum MD, Marquart JD, Bingham JL. Management considerations for giant congenital melanocytic nevi in aduits. Military medicine. 2014; 179:463-465.

16. Vissarionov VA, Chervonnaya LV, Ilina EE. Prodolzhennyiy rost nevusov posle ih udaleniya. Eksperimentalnaya i klinicheskaya dermatokosmetologiya. 2012; 4:27-30.

17. Castagna RD, Chemello RML. The recurrent nevus phenomenon. An Bras Dermatol. 2017; 92(4):531533. Available from: http://dx.doi.org/10.1590/abd1 806-4841.20176190 
УДК 616.5-003.829-089-053

\section{НЕКОТОРЫЕ ВОПРОСЫ ХИРУРГИЧЕСКОЙ ТАКТИКИ В ЛЕЧЕНИИ ПИГМЕНТНЫХ НЕВУСОВ У ДЕТЕЙ}

В.С. Коноплицкий, О.В. Пасичник, О.О. Калинчук, Д.В. Коноплицкий, С.С. Блажко

Винницукий национальный медицинский университет, кафедра детской хирургии,

2. Винница, Украина,

ORCID ID: 0000-0001-9525-1547,

ORCID ID: 0000-0001-8302-3520,

ORCID ID: 0000-0002-1918-0035,

ORCID ID: 0000-0002-1320-0541,

ORCID ID: 0000-0003-4891-5886,

e-mail:vkonoplytsky@gmail.com

Резюме. Статья содержит актуальную информацию о диагностике и лечении наиболее часто встречающихся форм меланоцитарных невусов у детей с указанием на их динамическую эволюцию в течение времени. Обсуждаются факторы риска и вопросы ранней диагностики меланомы в общей практике. Также обсуждается современное понимание рисков, связанных с врожденными меланоцитарными невусами разных размеров и стратегиями для ведения детей с врожденными и приобретенными меланоцитарными невусами.

Целью исследования было повышение качества лечения детей путем уточнения показаний и методов хирургического лечения пигментных невусов кожи.

Пигментные невусы относятся к доброкачественным образованиям, возникновения которых на современном этапе связывают с миграцией в эмбрионном периоде меланобластов из нейроэктодермальной трубки в базальный слой эпидермиса. У детей пигментные невусы встречаются достаточно часто в любом возрасте. Так у новорожденных пигментные невусы встречаются в 1-6\% общей популяции. Показания к профилактическому удалению невусов вытекают из проведенного анализа клинического материала: наличие симптомов активизации, в частности рост невуса; наличие в анамнезе факторов, способствующих активизации пигментных невусов повышенная солнечная инсоляция, травматизация, изменения гормонального фона; наличие признаков клеточной пролиферации; наличие очага терморазогрева в проекции пигментного невуса. Обязательным условием выполнения операции должно быть проведение морфологического исследования. Объем удаляемых тканей зависит от формы роста, размера невуса.

Ключевые слова: невус, диагностика меланомы.
UDC 616.5-003.829-089-053

\section{SOME ISSUES OF SURGICAL TACTICS IN THE TREATMENT OF PIGMENTAL NEVUS IN CHILDREN}

V.S. Konoplitskiy, O.V. Pasechnyk, A.A. Kalynchuk, D.V. Konoplitskiy, S.S. Blagko

\author{
National Pirogov Memorial \\ department of pediatric surgery, \\ Vinnytsia, Ukraine, \\ ORCID ID: 0000-0001-9525-1547, \\ ORCID ID: 0000-0001-8302-3520, \\ ORCID ID: 0000-0002-1918-0035, \\ ORCID ID: 0000-0002-1320-0541, \\ ORCID ID: 0000-0003-4891-5886, \\ e-mail:vkonoplytsky@gmail.com
}

Medical University,

Abstract. This review provides an update on common melanocytic nevi forms in children, focusing on their dynamic evolution over time. Increasing risk of melanoma in general practice are discussed. Current understanding of the risks associated with congenital melanocytic nevi of different sizes and strategies for the management of children with acquired and congenital nevi are also discussed.

The aim of the study was to improve the quality of treatment for children by clarifying the indications and methods of surgical treatment of pigmented skin nevi.

Pigmented nevi are benign formations, the occurrence of which at the present stage is associated with the migration in the embryonic period of melanoblasts from the neuroectodermal tube into the basal layer of the epidermis. According to recent researches, nevi in children are divided into congenital melanocytes, which are hamartomas due to clonal proliferation of benign melanocytes during embiogenesis, which may exist at birth or appear during the first years of life (the phenomenon of delayed clinical manifestation) and melanocyte nevi. Melanocyte nevi are benign tumors that arise from melanocytes that migrate into the skin in the embryonic period after 6 months of age, reach their maximum size in adolescence, and subsequently prone to regression and complete disappearance [3, 4]. All nevi are divided into melanoma-dangerous (pigmented borderline nevus, blue nevus, Otto's nevus, giant pigmented nevus, Dubreias melanosis) and melanoma-safe (intradermal pigmented nevus, fibroepithelial nevus, papillomatous nonvermicular and vermicular [6]. In general, the concept of pigmented nevus combines a number of skin lesions with general clinical and histological signs, a developmental disorder formed by mature or almost mature components of the epidermis, sebaceous glands, hair follicles, apocrine and eccrine sweat glands and their combinations. Pigmented nevi in $80 \%$ of cases are observed in the first year of life and are sporadic [7].

Indications for prophylactic removal of nevi are derived from the analysis of clinical material: symptoms' intensify, in particular, the growth of a nevus, a history of the factors contributing to enhancing pigmented nevi (increased solar radiation, trauma, hormonal changes), the presence of signs of cell proliferation in a cytogram, the presence of elevated temperature zone in the projec- 
tion of a pigment nevus. A morphological research should be a mandatory condition for preventive surgery. The amount of tissue removed depends on the type of growth, nevus size.

Due to the large number of pigmented nevi of different localization in childhood and a careful approach to determining the indications for surgical treatment, in the last decade there has been an extensional annual increase in the number of operated children. Indications for surgical removal of pigmented nevi in childhood should be based on clear clinical dynamic signs, primarily taking into account the localization in functionally active areas. In order to prevent the continued growth of pigmented nevi of any size, it is advisable to cut them within healthy skin in a circle to the fascial layer with simultaneous irradiation with a laser coagulator with a wavelength of $940 \mathrm{~nm}$.

Keywords: nevus, diagnosis of melanoma.

Стаття надійшла в редакцію 11.05.2020 р. 